\title{
A AMÉRICA LATINA NO CONTEXTO DO EMPREENDEDORISMO E INOVAÇÃO
}

DOI: http://dx.doi.org/10.18616/pers01

Millena Biff - UNESC

E-mail: millenabiff@outlook.com

Júlio Cesar Zilli - UNESC

E-mail: zilli42@hotmail.com 


\section{INTRODUÇÃO}

No atual mundo globalizado, é possível observar que algumas economias se sobressaem a outras e, portanto, que aquelas que não se evidenciam devem buscar maneiras para o fortalecimento, o crescimento e o aperfeiçoamento de seus produtos e serviços perante o mercado mundial. Uma dessas maneiras pode ser o empreendedorismo, que proporciona empregos, produtos e serviços melhores para a sociedade, principalmente quando aliado à inovação, até porque empresas que não inovam nem mudam o que oferecem, correm o risco de serem superadas pelas que o fazem (BESSANT; TIDD, 2009).

Nesse sentido, Schumpeter (1985) aponta que o empreendedorismo está associado ao desenvolvimento econômico, à inovação e ao aproveitamento de oportunidades. Ele é quem destrói a ordem econômica existente por meio da introdução de novos bens no mercado, pela criação de novas formas organizacionais ou pelo uso de novos materiais. Assim, tal processo é definido pelo autor como "destruição criativa".

A América Latina é uma região muito rica em recursos naturais, mas seus países não estão entre os mais desenvolvidos (GWYNNE; CRISTOBAL, 2014). Além disso, essa região presenciou um crescimento econômico e social relevante a partir dos anos 2000, mas vem decrescendo nos últimos anos (LEDERMAN et al., 2014).

Para que essas economias latino-americanas, em sua maioria exportadoras de commodities, voltem a crescer em um progresso contínuo, faz-se necessário um maior investimento em inovação e produtividade. Os empreendedores estão ligados a esse processo, tendo em vista que são eles que percebem as oportunidades existentes e aproveitam-nas. Assim, estudar os empreendedores latino-americanos é importante para que se detectem as mudanças que devem ser realizadas em suas mentalidades empreendedoras.

Dessa forma, o presente estudo teve como objetivo identificar o papel do empreendedorismo e da inovação na América Latina. Para melhor compreensão, é necessário entender o conceito de América Latina. No entendimento de Souza (2012), há muito tempo esse conceito é motivo de debates, interpretações divergentes e não há consenso sobre quem introduziu-o. Conforme Farret e Pinto (2011, p. 30), “[...] é muito difícil determinar quais países compõem-na, ou quais os critérios utilizados para classificar este ou aquele país americano como integrante dessa denominação". 
Para Bethell (2009), o termo é de origem francesa, derivado da terminologia Amérique Latine, usado primeiramente no século XIX por intelectuais franceses para justificar o imperialismo francês no México, sob o domínio de Napoleão III. Contudo, na interpretação de Morse (1988), Napoleão III só utilizou esse termo quase quatro séculos depois do descobrimento das índias ocidentais, como parte de um discurso "geoideológico" para uma suposta unidade linguística, cultural e racial dos povos latinos, de forma a se contrapor aos germânicos, anglo-saxões e eslavos. Para Feres Junior (2004), esse termo foi usado pela primeira vez em 1856, em um poema chamado "Las dos Américas", de José Maria Torres de Caicedo.

Em relação às definições e ao uso do termo, o Instituto de Estatística da Unesco - UIS (2001) afirma que a "América Latina" geralmente se refere ao conjunto de países da América Continental e Caribe, cujos habitantes falam espanhol e português. Contudo, D’Araujo (2006) tem outro ponto de vista. Para o autor, fazem parte da América Latina os países abaixo do Rio Grande, rio que separa os Estados Unidos da América do México, dos quais, além do México, sete países na América Central, 12 na América do Sul e 14 países do Caribe compõem o conjunto latino-americano.

Muitas vezes, para não haver dúvida quanto aos países participantes, autores utilizam a expressão "América Latina e Caribe", englobando a região caribenha. Mesmo assim, ainda há divergência nos conceitos. A Organização das Nações Unidas para a Alimentação e a Agricultura - FAO (2015) afirma que essa região compreende 46 países, territórios dependentes e departamentos ultramarinos. No entanto, o Programa das Nações Unidas para o Desenvolvimento - UNDP (s.d.) considera 42 países e territórios.

Nesse sentido, Bohoslavsky (2009) afirma que os parâmetros utilizados para classificar a região latino-americana são duvidáveis, até porque os próprios Estados Unidos da América têm muitos habitantes que falam espanhol como seu primeiro idioma, e cerca de $20 \%$ da população do país têm origem hispano-americana e não estão incluídos nessa lista de países. Além disso, o autor ressalta que definir a América Latina como um lugar onde são faladas as línguas dos países colonizadores parece ser algo para não incentivar o desenvolvimento de políticas emancipatórias, eternizando a relação de subordinados às metrópoles europeias.

A partir desse cenário, para as análises do presente capítulo e melhor assimilação do conteúdo abordado, foram adotados 20 países como América Latina, dentre eles Argentina, Bolívia, Brasil, Chile, Colômbia, Costa Rica, Cuba, Equador, El Salvador, Guatemala, Haiti, Honduras, México, Nicarágua, Panamá, Paraguai, Peru, República Dominicana, Uruguai e Venezuela. Os países selecionados não 
apresentam as mesmas características no que diz respeito ao tamanho de suas populações, estrutura e distribuição etária, bem como apresentam significativas diferenças na renda média de sua população e na sua distribuição na sociedade (UIS, 2001). Nesses países, observam-se as diferentes heranças culturais, as diferenças linguísticas, as variadas etnias e a rica e diversificada cultura, porém, em contrapartida, "[...] são em geral, países com uma dívida social imensa, com déficit democrático, déficit de direitos e com problemas na economia muito mais graves do que os do primeiro mundo." (D'ARAUJO, 2006, p. 1).

O capítulo foi estruturado em quatro seções: a primeira é a introdução; a segunda apresenta um contexto econômico latino-americano; a terceira apresenta os resultados da pesquisa, abordando o empreendedorismo e a inovação na América Latina e, por fim, as considerações finais e as referências.

\section{CONTEXTO ECONÔMICO LATINO-AMERICANO}

De acordo com Gwynne e Cristobal (2014), a globalização pode ser associada a uma série de mudanças econômicas, políticas, sociais e culturais na sociedade latino-americana. Nesse sentido, é importante demonstrar a relação que a globalização teve nos últimos anos com esses países. Assim, no âmbito internacional, a tabela 1 demonstra a balança comercial da América Latina do período de 2006 a 2013.

Tabela 1 - Balança comercial latino-americana em milhões de dólares FOB

\begin{tabular}{|c|c|c|c|c|c|c|}
\hline ANO & EXPORTAÇÃO & $\%$ PART & IMPORTAÇÃO & $\%$ PART & CORRENTE & SALDO \\
\hline 2006 & $762.849,8$ & 52,7 & $685.798,9$ & 47,3 & $1.448 .648,7$ & $77.050,9$ \\
\hline 2007 & $864.835,3$ & 51,3 & $819.395,4$ & 48,7 & $1.684 .230,7$ & $45.439,9$ \\
\hline 2008 & $983.060,8$ & 50,1 & $977.600,0$ & 49,9 & $1.960 .660,8$ & $5.460,8$ \\
\hline 2009 & $784.272,2$ & 50,7 & $762.761,9$ & 49,3 & $1.547 .034,1$ & $21.510,3$ \\
\hline 2010 & $985.168,4$ & 50,0 & $986.374,5$ & 50,0 & $1.971 .542,9$ & $1.206,1$ \\
\hline 2011 & $1.210 .584,6$ & 50,1 & $1.205 .928,6$ & 49,9 & $2.416 .513,2$ & $4.656,0$ \\
\hline 2012 & $1.232 .584,3$ & 49,4 & $1.260 .099,0$ & 50,6 & $2.492 .683,3$ & $27.514,7$ \\
\hline 2013 & $1.235 .689,3$ & 48,7 & $1.299 .137,2$ & 51,3 & $2.534 .826,5$ & $63.447,9$ \\
\hline TOTAL & 8.059.044,7 & 50,2 & 7.997.095,5 & 49,8 & $16.056 .140,2$ & $61.949,2$ \\
\hline
\end{tabular}

Fonte: Adaptada de CEPAL (2014).

Dessa forma, é perceptível que, no decorrer do período analisado, foi crescente o intercâmbio de bens e serviços dos países considerados latino-americanos; ou seja, houve um aumento dos bens e serviços que as nações comercializaram entre si e com os outros países ao redor do mundo. Visualiza-se, também, que 
nos últimos anos as importações têm uma tendência crescente, com uma maior participação na balança comercial quando comparadas às exportações. Isso significa que a América Latina, ultimamente, está adquirindo mais produtos e serviços do que outros países. Dos totais apresentados das exportações da região ao longo dos anos é possível distinguir quais valores são advindos da venda de bens e quais são da venda de serviços, conforme pode ser verificado no gráfico 1.

Gráfico 1 - Exportações latino-americanas por tipo / US\$ milhões - FOB

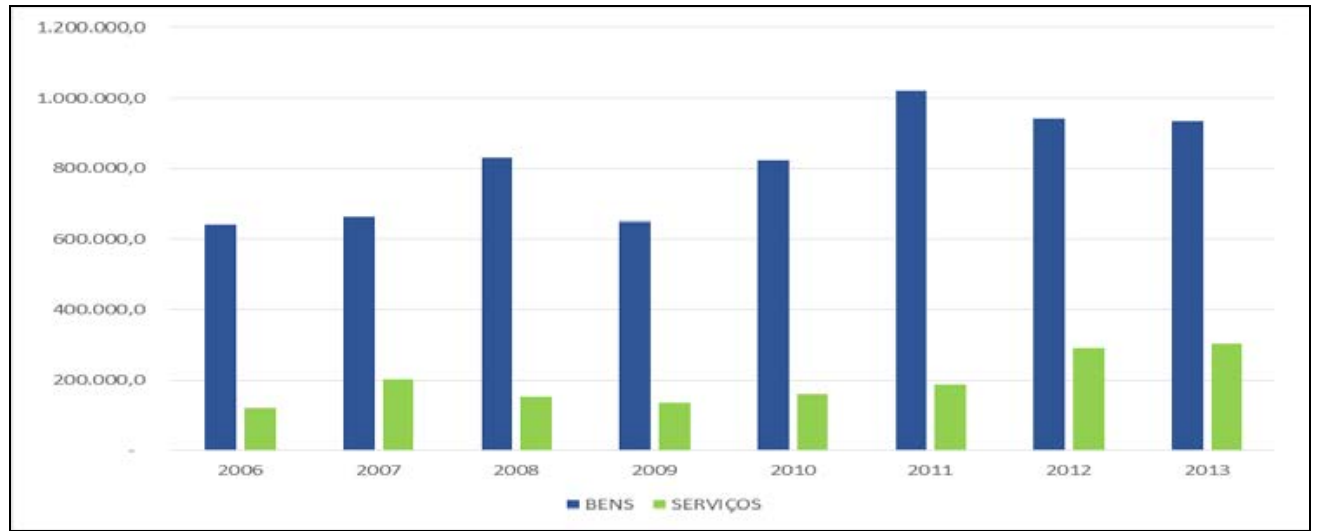

Fonte: Adaptado de CEPAL (2014).

Os bens representam a maior parte das exportações que a América Latina faz para os outros países e entre si. Esses bens são divididos em bens primários, que não sofreram transformações, e bens manufaturados, que sofreram. 0 gráfico 2 demonstra esse panorama das exportações latino-americanas.

Gráfico 2 - Exportações latino-americanas de bens por tipo / US\$ milhões- FOB

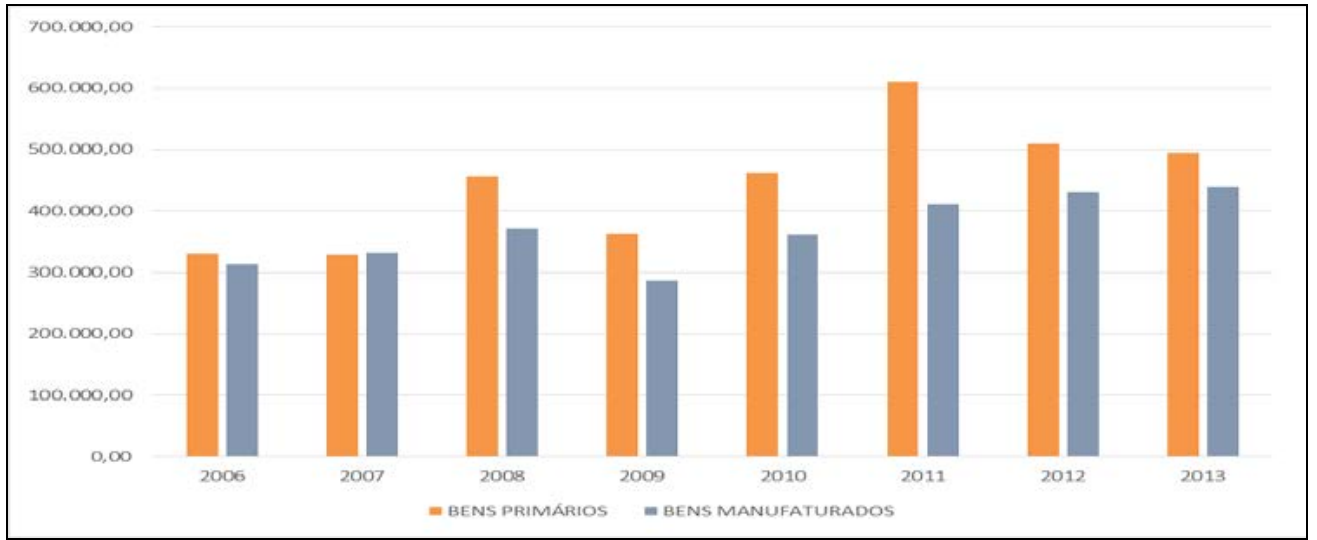

Fonte: Adaptado de CEPAL (2014). 
Nesse cenário, é perceptível que nos dois primeiros anos analisados (2006 e 2007) os bens primários e manufaturados tiveram, aproximadamente, a mesma representação no total de bens. Contudo, ao longo dos anos, houve um aumento das vendas de bens primários, com seu auge em 2011.

É importante ressaltar que as exportações de commodities minerais e agrícolas suprem uma grande parte da poupança e do investimento necessário para o desenvolvimento econômico da América Latina. Os países latino-americanos dependem fortemente das divisas geradas pelas exportações de commodities, haja vista que com elas fazem a troca por alimentos, tecnologia e pesquisa e desenvolvimento, peças-chave para o seu crescimento econômico. Assim, para impulsionar essas economias a se expandirem ou terem um rápido desenvolvimento, geralmente é necessário um aumento na taxa de extração de recursos naturais para vender mais nos mercados internacionais (GWYNNE; CRISTOBAL, 2014).

Nesse sentido, apontam Gwynne e Cristobal (2014) que a América Latina tem servido como uma periferia de recursos para a economia mundial desde os tempos coloniais. Nessa época, explica Quijano (2005), os colonizadores extraíam minerais (ouro e prata) e vegetais (tabaco, cacau e batata) preciosos por meio de mão de obra escrava, servos e de seus respectivos mestiços.

Nesse cenário, a América Latina é uma região extremamente rica em recursos naturais, o que poderia fazer com que ela estivesse entre os países mais desenvolvidos do mundo, porém este não é o cenário que se apresenta nos dias atuais. Ainda, várias iniciativas políticas apoiadas em ideias que visam quebrar a dependência do continente em matéria de desenvolvimento dos recursos não são totalmente bem-sucedidas. Assim, os países permanecem na periferia da economia mundial - em grande parte dependentes dos centros globais de bens de consumo e de mercados para seus produtos primários (GWYNNE; CRISTOBAL, 2014).

Sobre esses produtos primários, Gwynne e Cristobal (2014) apontam que alguns dados econômicos sugerem que as exportações de produtos primários renováveis e não renováveis tornaram-se menos importantes ao longo do tempo. Em 1970, as exportações foram responsáveis por $89,2 \%$ do valor total das exportações regionais. Porém, em 2000 , esse número baixou para $42 \%$. Em termos nominais, as exportações de valores e volumes de produtos primários continuam a aumentar, mas em termos reais não. Destaca-se que as exportações industriais aumentaram substancialmente em vários países, principalmente México e Brasil, que juntos representam em torno de $64 \%$ do valor de todas as exportações da América Latina (GWYNNE; CRISTOBAL, 2014). 
Bárcena et al. (2014) apontam que, com exceção do México e da América Central, a região tem pouca participação nas três cadeias de valores conhecidas como Fábrica América do Norte, Fábrica Europa e Fábrica Ásia. A região não é um importante fornecedor de bens intermediários não primários para qualquer uma dessas cadeias nem um grande importador de bens intermediários dos países participantes. O México é uma exceção, já que produtos de média tecnologia representam uma grande parte de suas exportações de bens intermédios aos seus parceiros do Acordo de Livre Comércio da América do Norte (NAFTA). Ao mesmo tempo, a integração do país na Fábrica América do Norte se dá, principalmente, na exportação de bens finais produzidos a partir de insumos importados, com pouco valor agregado no mercado interno.

Ainda sobre a relação da América Latina com a globalização, segundo Ayerbe (2002), após a década de 1980, a liberalização política e econômica veio a ser uma tendência predominante na região, com o fortalecimento da hegemonia dos setores favoráveis ao mercado e à iniciativa privada. Com o fim da Guerra Fria, foi reforçada a posição latino-americana como uma região autônoma e com seus projetos políticos independentes (SOUZA, 2012).

De acordo com Stallings e Peres (2002), nos últimos dez a quinze anos, a América Latina e o Caribe passaram por uma transformação política econômica mais representativa desde a Segunda Guerra Mundial. Por meio de uma série de reformas estruturais, muitos países deixaram de ser economias fechadas, subjugadas pelo Estado, característica do modelo de industrialização por substituição de importação para economias mais orientadas pelo mercado e mais abertas ao resto do mundo.

Aspectos complementares do processo beneficiaram a estabilidade macroeconômica, especialmente pelas taxas de inflação mais baixas e os crescentes gastos na área social. Os mentores das políticas possuíam expectativas de que essas mudanças acelerariam o crescimento da economia e aumentariam os ganhos de produtividade e, simultaneamente, levariam à criação de mais empregos e de maior igualdade (STALLINGS; PERES, 2002).

A industrialização da América Latina acompanha o padrão que predomina nos países capitalistas avançados na fase de expansão das duas primeiras décadas posteriores à Segunda Guerra Mundial: ênfase no setor de bens de consumo duráveis, metal-mecânica e de indústria química, bem como a utilização do petróleo como principal fonte energética (AYERBE, 2002).

Segundo o Instituto de Estatística da Unesco (2001), as décadas de 1960 e 1970, na América Latina, foram caracterizadas pelo crescimento do Produto 
Interno Bruto (PIB) per capita a uma taxa média anual de 2,5 e 3,5\%, respectivamente, porém, nos anos oitenta e noventa, houve uma crise econômica geral. A renda real per capita declinou na década de oitenta e somente aumentou relativamente no período entre 1990 e 1999, a uma taxa média anual de aproximadamente $1 \%$. A provável causa desses vinte anos de estagnação do crescimento da renda per capita foi a euforia econômica dos anos sessenta e setenta, que levou essas economias a contraírem um endividamento externo inviável (UIS, 2001).

Na década de 1970, os preços das commodities, das quais dependem fortemente essas economias (principalmente agrícolas e minerais), caíram drasticamente como resultado da recessão global que estava para surgir na década seguinte (UIS, 2001). Lederman et al. (2014) também apresentam que as principais economias da América Latina experimentaram um baixo crescimento ao longo das décadas anteriores a 2000. No início do século XX, uma média simples do produto interno bruto per capita da região foi em torno de $38 \%$ do que foi o dos Estados Unidos. Em 2012, essa relação foi em torno de 35\%. A variação significa que, por mais de 110 anos, as grandes economias da América Latina e Caribe cresceram em um ritmo mais lento do que o dos Estados Unidos e, mais importante, não foram capazes de aproveitar seu relativo subdesenvolvimento por se aproximarem dos Estados Unidos e de outras economias desenvolvidas que se tornaram as fontes de novas tecnologias.

$\mathrm{Na}$ década de 2000, de modo geral, a situação econômica dos países da América Latina e do Caribe foi relativamente favorável, com um crescimento generalizado e sustentado do PIB per capita, o que somente foi interrompido pela crise financeira internacional iniciada em 2008 (UNESCO, 2012).

Antes da crise, dados apontados pela Comissão Econômica para América Latina e Caribe (CEPAL) estimaram um crescimento médio anual do PIB de aproximadamente $5 \%$ para os países da região (UNESCO, 2012). Ainda, corroborando esse cenário, segundo a Organização Internacional do Trabalho - OIT (2013), a perda de dinamismo econômico impactou o mercado de trabalho na América Latina e no Caribe. Em 2013, os indicadores de trabalho revelaram um estancamento do progresso, que caracterizou os anos anteriores. Salários cresceram menos do que em anos anteriores, a informalidade não foi reduzida, a produtividade cresceu abaixo da média mundial e aumentou o desemprego entre os jovens nas áreas urbanas. 


\section{PROCEDIMENTOS METODOLÓGICOS}

Metodologicamente, quanto aos fins, este estudo caracteriza-se como uma pesquisa descritiva, e, quanto aos meios de investigação, como bibliográfica e documental (ANDRADE, 2002; GIL, 2007). A pesquisa bibliográfica e documental envolveu livros, artigos, publicações e estudos sobre a região latino-americana, com destaque para o estudo de Lederman et al. (2014), do World Bank, intitulado Latin American Entrepreneurs: Many Firms but Little Innovation.

Os dados coletados envolveram as características dos empreendedores latino-americanos, bem como suas peculiaridades, além de dados econômicos e sobre investimento em inovação, sendo que esses dados foram coletados em publicações anteriores a 2015, contando, também, com a participação de publicações da Comissão para a América Latina e o Caribe (CEPAL), Banco Interamericano de Desenvolvimento (BID) e o Global Entrepreneurship Monitor (GEM).

\section{RESULTADOS E DISCUSSÃO}

\section{EMPREENDEDORISMO NA AMÉRICA LATINA}

Segundo Lederman et al. (2014), empreendedores exitosos prosperam em ambientes economicamente propícios, pois assim eles se arriscam, investem em inovação e estimulam a produtividade. Nesse sentido, o gráfico 3 demonstra a transição do trabalho autônomo ao emprego assalariado, que também está ligado ao crescimento econômico. É possível visualizar que o panorama do emprego muda quando o Produto Interno Bruno (PIB) aumenta ou diminui.

Assim, até aproximadamente US\$ 2.000 de produto interno bruto (PIB) per capita, os trabalhadores agrícolas constituem a maioria da população ativa, seguidos dos profissionais autônomos que não são agricultores e, depois, pelas pessoas assalariadas que não trabalham com agricultura. A partir desse valor, o emprego assalariado aumenta gradualmente e se transforma no tipo de emprego mais importante quando se alcança um nível de PIB per capita de mais ou menos US\$ 5.000 (LEDERMAN et al., 2014).

Desse modo, sabendo que o PIB médio da América Latina, em 2013, foi de US\$ 9.114,5 (CEPAL, 2015), compreende-se que ela estaria em uma situação em 
que aproximadamente $60 \%$ da população é assalariada, $20 \%$ são trabalhadores agrícolas e o restante está dividido entre as demais classificações.

Gráfico 3 - Transição de emprego conforme PIB per capita em dólares

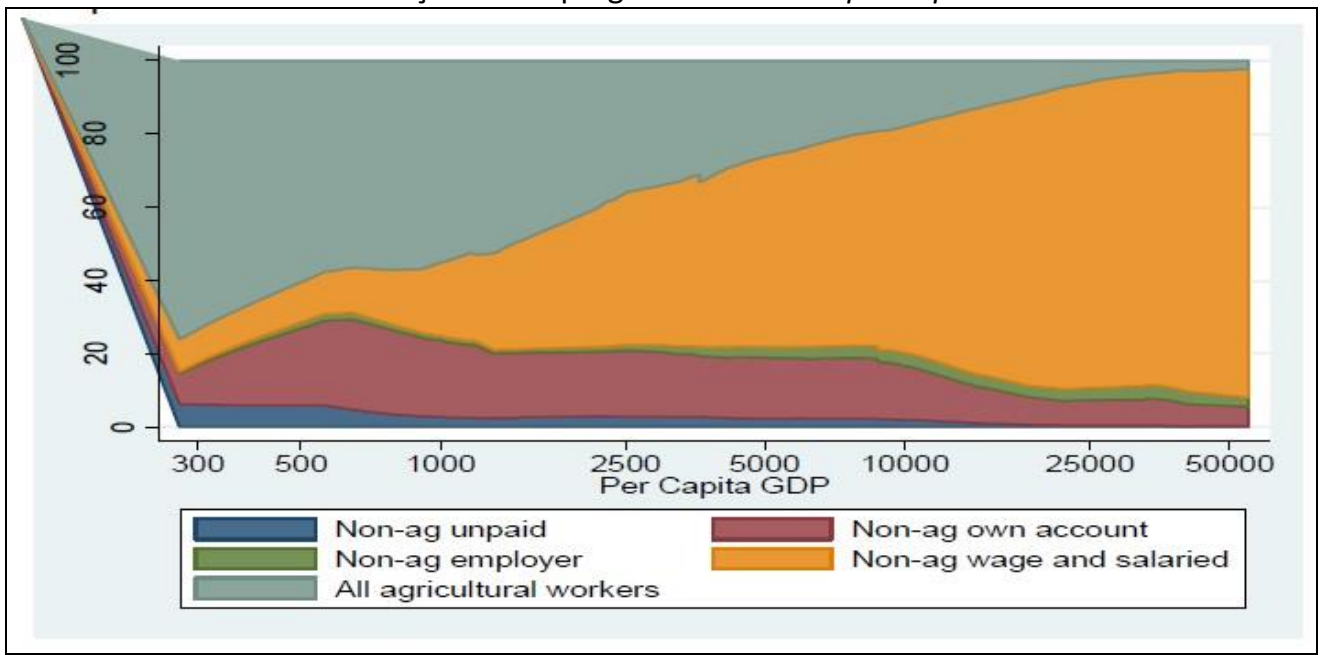

Fonte: Gindling e Newhouse (2012).

Dessas demais classificações, uma que merece destaque é a de "empregadores não agrícolas", aparecendo com pequena parcela (em verde) em todos os PIB analisados. No entanto, há um leve crescimento conforme o PIB aumenta. Empregadores não agrícolas são pessoas que abrem empresas e fornecem empregos formais, também, na maioria das vezes, são os que tiveram mais acesso à educação (GINDLING; NEWHOUSE, 2012).

A tabela 2 demonstra o percentual de pessoas da força de trabalho latino-americana que, em 2014, eram donos e gerentes de empresas que funcionam há pelo menos três anos e meio, bem como o percentual da força de trabalho que não estava envolvida com atividades empreendedoras e tinha a intenção de ser empreendedora nos próximos três anos.

Tabela 2 - Percentual de propriedade e intenção empreendedora - 2014

\begin{tabular}{lrr}
\hline Países & Propriedade & Intenção \\
\hline Argentina & 9,1 & 27,8 \\
\hline Bolívia & 7,6 & 46,9 \\
\hline Brasil & 17,5 & 24,5 \\
\hline Chile & 8,8 & 50,1 \\
\hline Colômbia & 4,9 & 47 \\
\hline
\end{tabular}




\begin{tabular}{lrr}
\hline Países & Propriedade & Intenção \\
\hline Costa Rica & 2,5 & 29 \\
\hline El Salvador & 12,7 & 23,1 \\
\hline Equador & 17,7 & 43,1 \\
\hline Guatemala & 7,4 & 35,8 \\
\hline México & 4,5 & 17,4 \\
\hline Panamá & 3,4 & 19,7 \\
\hline Peru & 9,2 & 50,6 \\
\hline Uruguai & 6,7 & 24,8 \\
\hline Média da região & $\mathbf{8 , 6 2}$ & $\mathbf{3 3 , 8 3}$ \\
\hline
\end{tabular}

Fonte: Adaptada de GEM (2015).

Pode-se perceber que, em 2014, nos países analisados, a porcentagem de donos e gerentes de empresas estava entre 2,5\% e 17,7\% - este último alcançado pelo Equador. Com exceção deste índice e o do Brasil, os demais países alcançaram percentuais de menos de $15 \%$. A média da taxa de propriedade da região era de $8,62 \%$. Ao contrário do esperado pelo PIB per capita da região, a América Latina mostrou-se uma região de empreendedores, havendo um elevado número de empresários em comparação com outros países (LEDERMAN et al., 2014). Além disso, Lederman et al. (2014) afirmam que o grande número de empreendedores não é um simples reflexo de um grande setor informal, pois o percentual de empresários cujas empresas estão registradas formalmente também é alto na América Latina.

Ainda, a partir da análise dos dados, verificou-se que cerca de $30 \%$ das pessoas que compunham a força de trabalho, embora não estivessem envolvidas com o empreendedorismo, pretendiam abrir um negócio nos próximos três anos. Nesse sentido, conforme constatações anteriores, também se faz importante mostrar a taxa de Atividade Empreendedora Total (Total Entrepreneurship Activity - TEA), ou seja, o percentual dos componentes da força de trabalho que estão envolvidos na criação e no desenvolvimento de novos negócios (MEZA et al., 2008), de acordo com o gráfico 4. 
Gráfico 4 - Atividade Empreendedora Total (TEA)

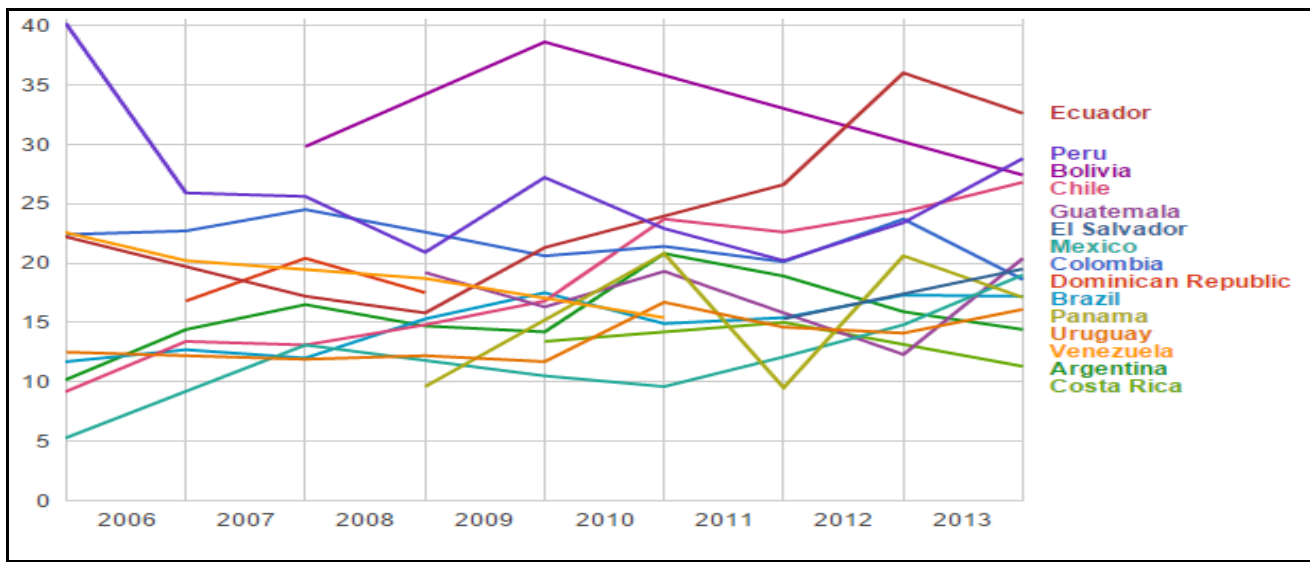

Fonte: GEM (2015).

Segundo Meza et al. (2008), a média da TEA no mundo é de 9,5\%, e a América Latina é a região mais empreendedora se comparada com as demais, pois, conforme o gráfico 4, possui percentuais acima de $10 \%$ na maioria dos países e períodos analisados. Desses novos negócios, também é possível perceber o percentual de homens e de mulheres componentes da força de trabalho que fazem parte da TEA. O quadro 1 demonstra essa relação de alguns países da América Latina.

Quadro 1 - Percentual de empreendedores iniciantes ou proprietários-gerentes de um novo negócio (por gênero)

\begin{tabular}{|c|c|c|c|c|c|c|c|c|c|c|c|c|}
\hline & \multicolumn{2}{|c|}{2010} & \multicolumn{2}{|c|}{2011} & \multicolumn{2}{|c|}{2012} & \multicolumn{2}{|c|}{2013} & \multicolumn{2}{|c|}{2014} & MÉDIA ANOS & MÉDIA ANOS \\
\hline AMÉRICA LATINA & 17,26 & 20,65 & 17,94 & 22,80 & 17,18 & 21,99 & 17,27 & 23,90 & 19,24 & 23,21 & 17,78 & 22,51 \\
\hline 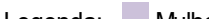 & & & nens & & & & & & & & & \\
\hline
\end{tabular}

Fonte: Elaboração própria a partir de dados de GEM (2015) sobre os seguintes países: Argentina, Bolívia, Brasil, Chile, Colômbia, Costa Rica, Equador, Guatemala, México, Peru e Uruguai.

Em todos os anos analisados, o homem foi o que mais esteve presente como empreendedor, o que acontece na maioria dos países do mundo (GEM, 2010). Porém, o percentual de mulheres empreendedoras na região aumentou significativamente em 2014 se comparado com os anos anteriores, o que pode indicar que as mulheres estão se fortalecendo nessa atividade. Também é possível visualizar, por meio do gráfico 5, qual o percentual desses empreendedores, homens e mulheres, que esperam crescer nos próximos cinco anos, empregando pelo menos mais cinco novos funcionários. 
Gráfico 5 - Expectativa de crescimento do total de atividade empreendedora em estágio inicial: prevalência relativa

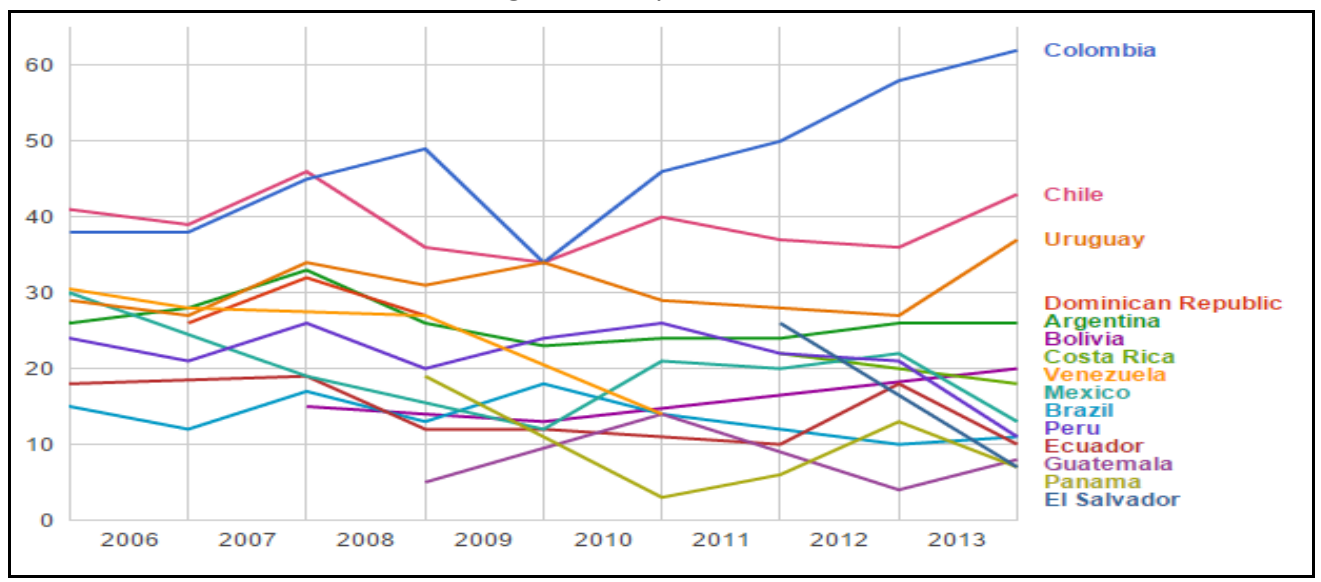

Fonte: GEM (2015).

Analisando os dados, infere-se que a Colômbia é o país onde os empreendedores mais esperam crescer e fazer novas contratações. Além disso, a partir de 2009, esse índice aumentou. No geral, os percentuais latino-americanos estão entre $10 \mathrm{e}$ $40 \%$, o que indica uma taxa não tão diferente dos países desenvolvidos, pois nesses o percentual compreende entre 20 e $40 \%$. Isso significa que a perspectiva de crescimento dos países latino-americanos é similar a dos países mais desenvolvidos.

Apesar de existirem indivíduos abrindo negócios formais, ainda há muitas pessoas que investem, informalmente, em empreendimentos, ou seja, disponibilizam recursos para negócios iniciados por outras pessoas, como familiares próximos, parentes, amigos e vizinhos, colegas de trabalho, entre outros, mas não com a compra de ações ou a participação em fundos de investimento (GEM, 2004; ANDREASSI et al., 2012). A tabela 3 demonstra o percentual da força de trabalho dos que, em 2012, foram investidores informais, investindo em negócios iniciados por outras pessoas nos últimos três anos, bem como demonstra o valor médio do qual essas pessoas despenderam.

Tabela 3 - Percentual de investidores informais e valor médio investido (em US\$) - 2012

\begin{tabular}{lrr}
\hline Países & Percentual (\%) & Valor médio investido (em US\$) \\
\hline Argentina & 3,58 & $8.487,00$ \\
\hline Brasil & 1,71 & $6.195,00$ \\
\hline Chile & 11,30 & $2.250,00$ \\
\hline Colômbia & 8,58 & $3.840,00$ \\
\hline
\end{tabular}




\begin{tabular}{lrr}
\hline Países & Percentual (\%) & Valor médio investido (em US\$) \\
\hline Costa Rica & 3,48 & $9.498,00$ \\
\hline El Salvador & 4,07 & $4.325,00$ \\
\hline Equador & 5,44 & $1.358,00$ \\
\hline México & 5,44 & $1.775,00$ \\
\hline Panamá & 1,50 & $3.792,00$ \\
\hline Peru & 6,09 & $2.232,00$ \\
\hline Uruguai & 4,68 & 905,00 \\
\hline Média da região: & $\mathbf{5 , 0 8}$ & $\mathbf{4 . 0 5 9 , 7 3}$ \\
\hline
\end{tabular}

Fonte: Adaptada de Andreassi et al. (2012).

Países mais desenvolvidos têm taxas menores de investidores informais que os países da América Latina, em torno de 2,60\%. Mas os países latino-americanos gastam menos nesses tipos de investimentos. Conforme a tabela 6 , a média da região é de US\$ 4.059,73. Já os países com um nível de desenvolvimento mais elevado investem em torno de US\$40.000,00 (ANDREASSI et al., 2012).

Em suma, isso significa que, apesar de os latino-americanos investirem mais em negócios informais que os países desenvolvidos, os valores investidos são menores. Nesse sentido, GEM (2004) afirma que quando os valores investidos são baixos, os empreendedores, formuladores de políticas e programas, educadores e pesquisadores, precisam dedicar mais atenção aos investidores informais, pois sem eles a dinâmica empreendedora sofre significativo desgaste, visto que é graças a eles que muitos negócios conseguem ser iniciados. Dessa forma, é importante mostrar o panorama das razões que levam as pessoas a se arriscarem no mundo dos negócios na América Latina.

Nesse cenário, conforme apontado por GEM (2015), as pessoas criam empreendimentos por diversas razões, uma delas pode ser a necessidade, ou seja, montar um negócio quando não há melhores opções de trabalho, bem como há a necessidade de se ter renda. Em contraste, empreendimentos podem ser iniciados pelo desejo de manter ou melhorar a renda e a independência, e não por não ter outra opção de trabalho. Essa atitude é denominada empreendedorismo por oportunidade, em que o indivíduo identifica uma oportunidade de negócio e a persegue.

Na América Latina, a maioria das pessoas abre um negócio por avistar uma oportunidade $(50,46 \%)$, porém os percentuais de empreendimentos iniciados por necessidade também são representativos $(25,54 \%)$, principalmente na Guatemala, onde o empreendedorismo por necessidade é maior que o por oportunidade, com 
taxas de $41 \%$ e $39 \%$, respectivamente (GEM, 2015). Segundo o GEM (2004, p. 27), "[...] quanto mais alto for o nível de escolaridade de um país, maior será a proporção de empreendedorismo por oportunidade". Ainda com relação à criação de empreendimentos, também é possível perceber o percentual das pessoas, componentes da força de trabalho, que acham que o empreendedorismo é uma boa opção de carreira, ou seja, algo que as pessoas desejam ser. Segundo Andreassi et al. (2012), a atividade empreendedora como carreira é fundamental para o desenvolvimento do empreendedorismo, porém é importante que ela esteja relacionada ao empreendedorismo por oportunidade e não por necessidade.

Os percentuais latino-americanos de pessoas que pensam que o empreendedorismo é uma boa opção de carreira encontram-se entre $60 \%$ e $95 \%$, o que indica que mais da metade das pessoas acham que começar um negócio é uma opção de carreira desejável. "Status, respeito, atenção da mídia, aceitação social, oportunidade de desenvolvimento pessoal e enriquecimento certamente são estímulos que motivam os indivíduos a perseguir uma carreira empreendedora." (ANDREASSI et al., 2012, p. 32). Assim, conforme o exposto, podem ser analisados alguns itens que estimulam as pessoas a ter uma carreira empreendedora.

A tabela 4 demonstra os percentuais da força de trabalho que acreditam que um empreendedor de sucesso, em seu país, possui elevado status perante a sociedade, bem como os que afirmam que verão casos de empreendedorismo de sucesso na mídia.

Em suma, cerca de $70 \%$ das pessoas trabalhadoras concordam que empreendedores de sucesso possuem alto status em seu país, sendo o Brasil o país latino-americano que mais afirmou isso. Quanto à atenção da mídia, Brasil, Peru, Equador e Costa Rica foram os países onde o percentual de pessoas que afirmaram que observam casos de empreendedorismo de sucesso na mídia foi maior. Ambas médias dos itens analisados foram similares, por volta de $67 \%$, verificando, assim, a importância que as pessoas dão a esses itens. Com o exposto, percebe-se que a mídia é uma grande divulgadora do empreendedorismo e que adquirir alto status é algo que os empreendedores conseguem.

Tabela 4 - Empreendedorismo: alto status e atenção da mídia - 2014

\begin{tabular}{lrr}
\hline Países & Status & Mídia \\
\hline Argentina & 59,49 & 63,5 \\
\hline Bolívia & 74,5 & 70,5 \\
\hline Brasil & 82 & 84 \\
\hline Chile & 67 & 66 \\
\hline
\end{tabular}




\begin{tabular}{lrr}
\hline Países & Status & Mídia \\
\hline Colômbia & 71 & 68 \\
\hline Costa Rica & 65,49 & 79,5 \\
\hline El Salvador & 65,49 & 61 \\
\hline Equador & 68 & 79 \\
\hline Guatemala & 71 & 55 \\
\hline México & 62 & 51 \\
\hline Panamá & 59 & 70 \\
\hline Peru & 71 & 71 \\
\hline Uruguai & 56 & 58 \\
\hline Média da região & $\mathbf{6 7 , 0 7}$ & $\mathbf{6 7 , 4 2}$ \\
\hline
\end{tabular}

Fonte: Adaptada de GEM (2015).

As pessoas podem iniciar novos negócios ao perceberem boas oportunidades e terem as habilidades necessárias e conhecimento para iniciá-los, ou seja, possuírem capacidade. Capacidades seriam os conhecimentos, as habilidades e as atitudes que foram desenvolvidas em diversas situações (como a formação superior, a experiência prática) e que podem ser utilizadas em situações específicas no trabalho (RUAS, 2005).

A tabela 5 demonstra o percentual de pessoas componentes da força de trabalho que afirmam identificar oportunidades de iniciar novos negócios na cidade onde vivem, bem como o percentual das que afirmam ter as habilidades necessárias para iniciar um empreendimento. Também demonstra as pessoas que, apesar de perceberem as oportunidades, afirmam que o medo de fracassar as impediria de criar uma empresa.

Tabela 5 - Percepção de oportunidades e capacidades, além do medo do fracasso - 2014

\begin{tabular}{lrrr}
\hline Países & Oportunidade & Capacidade & Medo fracasso \\
\hline Argentina & 32 & 58 & 24 \\
\hline Bolívia & 58 & 73 & 38 \\
\hline Brasil & 56 & 50 & 36 \\
\hline Chile & 67 & 65 & 28 \\
\hline Colômbia & 66 & 57 & 31 \\
\hline Costa Rica & 39 & 59 & 37 \\
\hline El Salvador & 45 & 71 & 35 \\
\hline Equador & 62 & 73 & 31 \\
\hline Guatemala & 45 & 64 & 33 \\
\hline México & 49 & 53 & 30 \\
\hline Panamá & 43 & 54 & 15 \\
\hline
\end{tabular}




\begin{tabular}{lrrr}
\hline Países & Oportunidade & Capacidade & Medo fracasso \\
\hline Peru & 62 & 69 & 29 \\
\hline Uruguai & 46 & 63 & 27 \\
\hline Média da região & $\mathbf{5 1 , 5 4}$ & $\mathbf{6 2 , 2 3}$ & $\mathbf{3 0 , 3 1}$ \\
\hline
\end{tabular}

Fonte: Adaptada de GEM (2015).

Dessa forma, mais da metade da força de trabalho latino-americana percebe oportunidades, com uma média de 51,54\% em 2014, e afirma ter as capacidades necessárias para iniciá-las. Porém, o medo de fracassar pode ser um dos fatores que impedem esses indivíduos de colocarem essas oportunidades em prática, visto que esse percentual é alto, em torno de 30,31\%. Mas, ainda assim, em países desenvolvidos, os percentuais de medo do fracasso costumam ser maiores, entre 25 e 55\%. Embora se suponha que em países mais desenvolvidos o medo do fracasso seja menor graças a todo o suporte neles existentes para as atividades empreendedoras, o que acontece não é isso. Em virtude de os projetos de empreendedorismo nesses países serem mais inovadores e envolverem maior investimento, o risco tende a ser relativamente mais elevado (ANDREASSI et al. 2012).

\section{INOVAÇÃO NA AMÉRICA LATINA}

As empresas da $A L$ introduzem novos produtos com menos frequência que as empresas de economias parecidas. Também o investimento em Pesquisa e Desenvolvimento (P\&D) e os registros de patentes estão abaixo dos níveis de referência (LEDERMAN et al., 2014). A porcentagem de empresas que se envolvem em atividades inovadoras por meio da inserção de novos produtos foi mais baixa em países latino-americanos que em outros países durante o período de 2006 a 2010. A Argentina foi o país latino-americano que apresentou maior percentual, com em torno de $70 \%$ das empresas introduzindo novos produtos no mercado.

Assim, o gráfico 6 demonstra a percepção da introdução de novos produtos do ponto de vista dos empreendedores latino-americanos. Apresenta o percentual dos componentes da TEA, os quais indicam que o seu produto ou serviço é novo para pelo menos alguns clientes e que afirmam não haver muitos concorrentes oferecendo o mesmo produto ou serviço na localidade onde atuam. 
Gráfico 6 - Novo produto em uma atividade empreendedora em estágio inicial

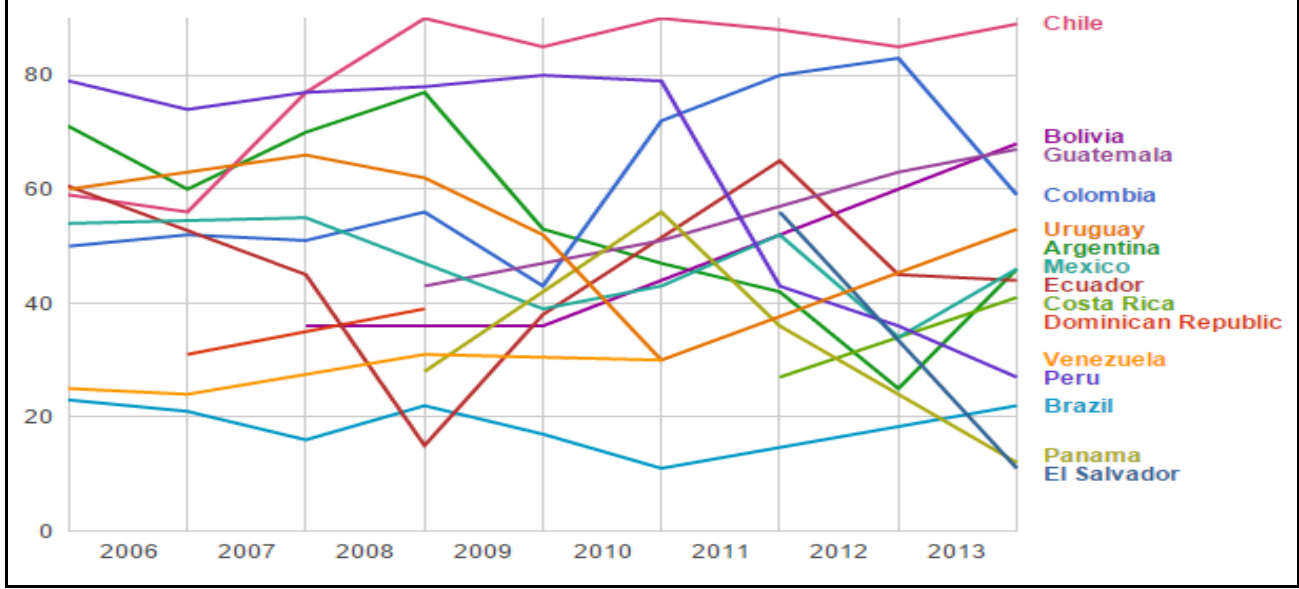

Fonte: GEM (2015).

Denota-se uma grande disparidade na região no quesito de introduzir novos produtos, sendo o Chile o país onde os empreendedores mais indicam que seus produtos são novos, contrastando com o Brasil, país onde há menos produtos novos introduzidos ao longo dos anos. Isso pode indicar, também, que há poucos concorrentes para as empresas que inserem novos produtos no Chile e mais concorrentes conforme os percentuais vão diminuindo.

Segundo Lederman et al. (2014), a qualidade da educação na América Latina também pode explicar a falta de inovação na região. A região carece de engenheiros e cientistas, considerados um capital humano importante para a inovação, visto que são eles que normalmente fazem pesquisas e projetam novos produtos.

Com exceção de Cuba, o restante dos países latino-americanos investiu percentuais abaixo de 7\% de seu PIB em educação em 2013, sendo que o Haiti é o país que menos investe, utilizando menos de $2 \%$. Apesar de vários países investirem o mesmo que países desenvolvidos, o retorno esperado por esse investimento não acontece.

Quanto ao capital humano, a quantidade que um país tem dele é medida por meio da média de anos de escolarização da população ativa e a qualidade da educação, que por sua vez é medida pelos resultados obtidos em provas acadêmicas padronizadas (LEDERMAN et al., 2014). Ambas as médias, segundo Ferreira et al. (2013), são menores na América Latina que em outros países comparados.

A quantidade de engenheiros nos países latino-americanos está abaixo do esperado pelo seu desenvolvimento econômico atual. O número de engenheiros 
é baixo, inclusive nos dois países latino-americanos que mais intercambiam bens com o mundo: Brasil e México (LEDERMAN et al., 2014). Ainda segundo Lederman et al. (2014), por razões históricas, as universidades da América Latina sempre enfatizaram os cursos de humanas, direito e disciplinas sociais, econômicas e políticas, o que pode ter restringido sua capacidade de formar engenheiros e cientistas.

Pode ser que os jovens se sintam mais atraídos pelas disciplinas relevantes para os problemas por que passam suas sociedades, o que explicaria porque há tantos sociólogos se formando na América Latina, assim como mais macroeconomistas que microeconomistas. No gráfico 7 , fica perceptível essa diferença na área de formação dos pesquisadores.

Gráfico 7 - Distribuição de pesquisadores por área científica - 2007

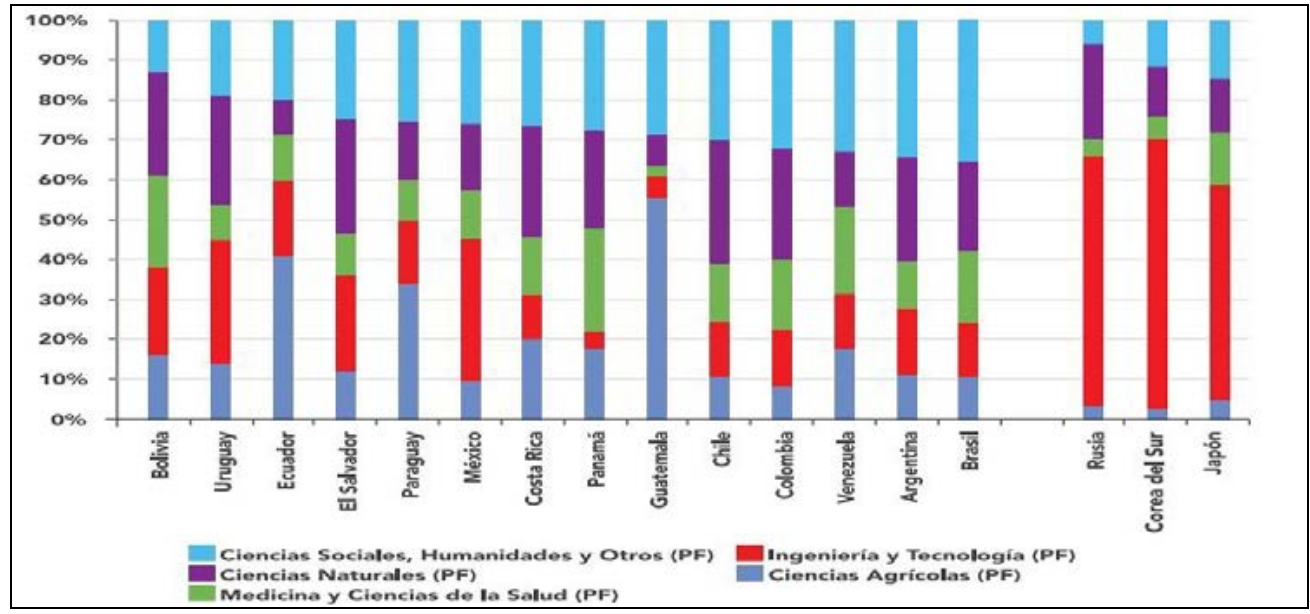

Fonte: Adaptado de BID (2011).

Dessa forma, percebe-se que os pesquisadores em economias mais desenvolvidas são, em sua maioria, da área de engenharia e tecnologia, contrastando com os países latino-americanos, que investem mais em ciências sociais e ciências agrícolas, esta última quase não aparecendo nos países com economias desenvolvidas. A proporção dos pesquisadores que se dedicam à engenharia e à tecnologia oscila entre $10 \%$ e $30 \%$ na América Latina, enquanto que países como Japão e Coreia do Sul registram taxas por volta de 60\% (BID, 2011). Lederman et al. (2014) afirmam que as empresas latino-americanas investem pouco em pesquisa e desenvolvimento $(P \& D)$ e a atividade de registro de patentes está abaixo dos níveis de referência. 
O gráfico 8 demonstra os gastos com $P \& D$ que os países latino-americanos e outros países tiveram em 1998 e 2008.

Gráfico 8-Gastos do PIB com P\&D em 1998 e 2008

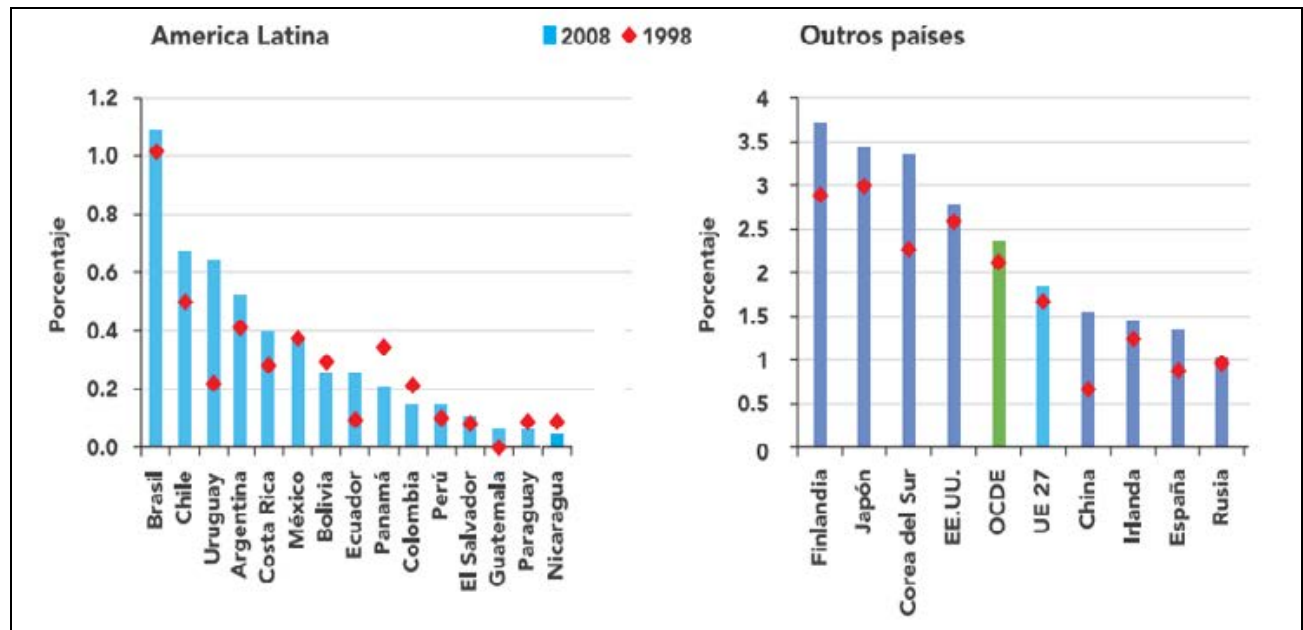

Fonte: Adaptada de BID (2011).

Enquanto que a participação dos gastos com P\&D no PIB cresceu nas economias mais avançadas, entre 1998 e 2008, nos países da América Latina, as melhoras foram modestas (BID, 2011). Ao contrário de economias desenvolvidas, em que a maioria dos países continua a aumentar esse investimento, na América Latina, os esforços para melhorar o investimento em $P \& D$ estão concentrados em poucos países. Em 2007, 60\% das despesas em P\&D da região foram do Brasil (BID, 2011).

O BID (2011) afirma que outra característica da América Latina é a falta de participação do setor privado na inovação. O financiamento de P\&D continua altamente concentrado em instituições públicas (agências governamentais e universidades) e constitui $59 \%$ do investimento total, enquanto na OCDE o número é de $35 \%$.

O gráfico 9 demonstra os gastos de alguns países da América Latina por fonte de financiamento, bem como os gastos de outros países para que se possa fazer um comparativo. 
Gráfico 9-Gastos com P\&D por fonte de financiamento - 2008

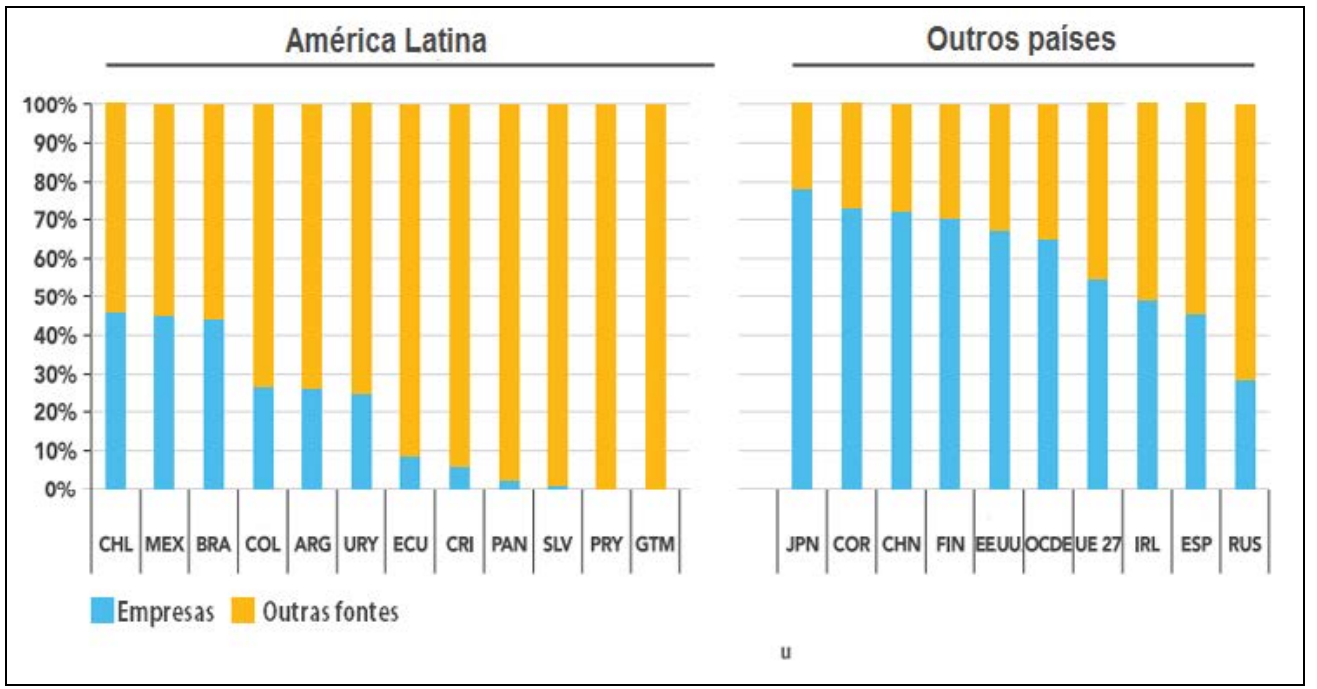

Fonte: Adaptado de BID (2011).

Assim, percebe-se que nenhum país latino-americano exposto tem financiamento de mais de $50 \%$ advindo de empresas, enquanto que nos outros países, em sua maioria, predominam esse tipo de financiamento. Dessa forma, fica visível como é importante as empresas conscientizarem-se acerca da importância do investimento em P\&D para a sua competitividade. A região ainda é muito dependente de outras fontes para investir em $P \& D$, necessitando ser mais independente. A América Latina é muito empreendedora, mas se esses empreendedores não buscarem formas para se fortalecer e se diferenciar, não poderão competir em mercados internacionais e, possivelmente, suas empresas não durarão muito tempo no mercado.

Sobre os registros de patentes, também se faz necessário analisá-los para que se tenha entendimento de como está a criação de novos produtos e tecnologias na América Latina.

Não há nenhum país na América Latina cujo número de patentes se aproxima do nível de países de alta renda; além disso, a maioria dos países latino-americanos registrou menos patentes que países com renda similar. O Brasil, por exemplo, registrou apenas cinco patentes por milhão de pessoas entre 2006 e 2010, metade do valor per capita da China (10) e pouco menos de um quarto do nível per capita da Bulgária (22) (LEDERMAN et al., 2014).

Pode-se dizer que o acesso a novos mercados por meio do comércio também é um dos sintomas do empreendedorismo transformador. Em mercados de 
exportação prosperam apenas as empresas com o melhor desempenho, tanto é que a maioria das empresas que entram nos mercados de exportação não sobrevive mais de um ano (LEDERMAN et al., 2014). A partir desse cenário, no âmbito das exportações de tecnologia, o gráfico 10 apresenta os percentuais de exportação desses produtos manufaturados nos países latino-americanos e em outros países.

Gráfico 10 - Exportações de alta tecnologia (porcentagem de exportações manufaturadas) nos anos de 1998 e 2008

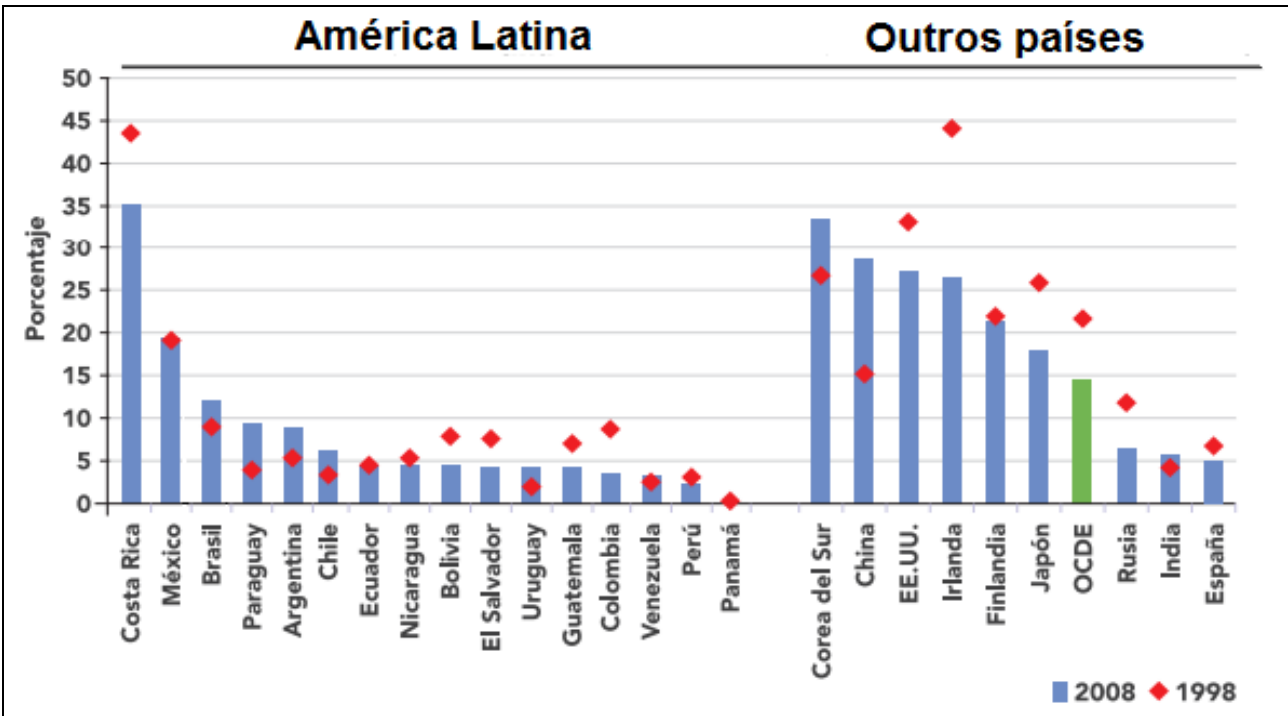

Fonte: Adaptado de BID (2011).

Dessa forma, fica perceptível que a maioria dos países latino-americanos exporta menos tecnologias que outros países. Apesar de a Costa Rica ter uma porcentagem de $30 \%$ na exportação desses produtos no ano de 2008, em 1998, ela exportou quase $45 \%$, o que indica que suas exportações de tecnologia decaíram. No geral, a América Latina exportou menos de $15 \%$ durante os dois anos analisados, enquanto que países como a China e a Irlanda e os participantes da OCDE exportaram mais de $15 \%$. Assim, conforme mencionado no contexto econômico da região, a América Latina é uma grande exportadora de bens primários, não se sobressaindo nas exportações de bens manufaturados, principalmente de alta tecnologia.

Ainda sobre as exportações, na percepção dos próprios empreendedores, o gráfico 11 demonstra o percentual da TEA, que indica que pelo menos $25 \%$ dos seus clientes são de outros países, independentemente do tipo de produto 
exportado, promovendo a visualização dos negócios novos ou em desenvolvimento, que possuem clientes internacionais.

Gráfico 11 - Atividade empreendedora em estágio inicial (TEA) orientada internacionalmente

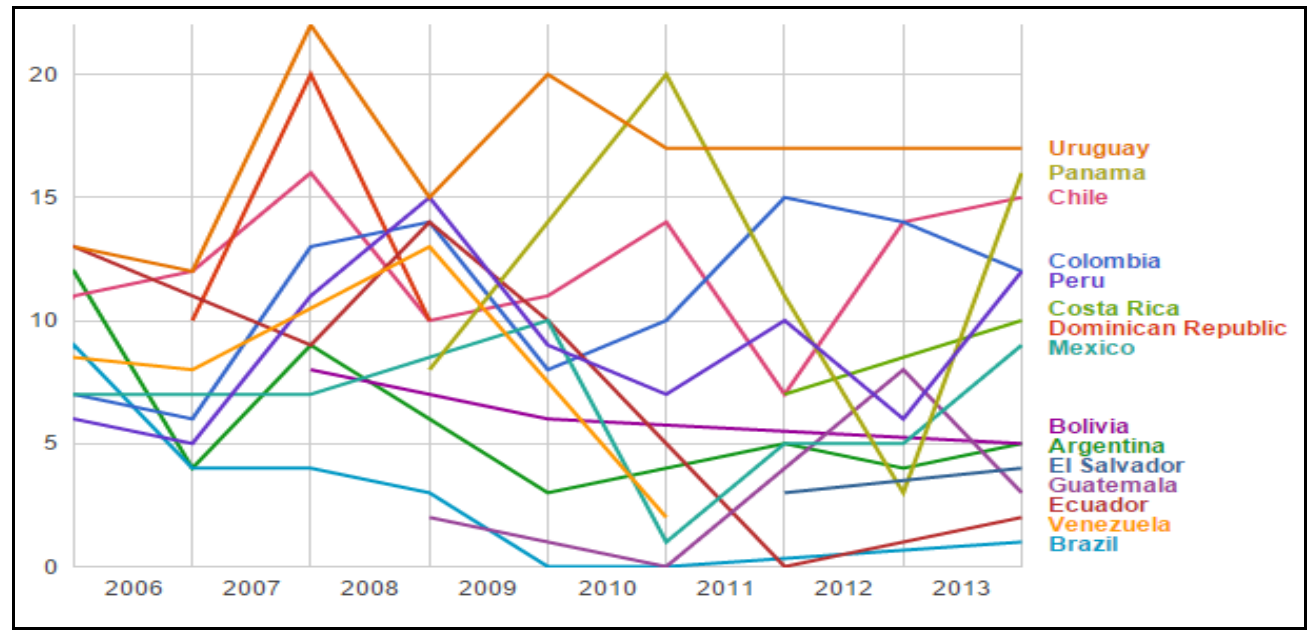

Fonte: GEM (2015).

Percebe-se que quando os negócios são novos ou estão em recente desenvolvimento menos de $20 \%$ dos clientes da região são internacionais. O Brasil foi o país que, durante o período exposto, teve percentuais mais baixos, chegando a praticamente 0\% em 2009 e 2010. Os percentuais da América Latina, com exceção dos abaixo de $5 \%$, segundo os dados da pesquisa GEM (2015), podem ser considerados dentro do normal, se comparados com países como Alemanha, Estados Unidos e Japão.

Uma síntese dos principais resultados da pesquisa é apresentada no quadro 2 .

Quadro 2 - Síntese dos resultados

\begin{tabular}{|c|c|}
\hline CONTEXTO & CARACTERÍSTICAS \\
\hline Contexto econômico & $\begin{array}{l}\text { i) Importações em tendência crescente; } \\
\text { ii) Maioria das exportações são de bens primários. }\end{array}$ \\
\hline Empreendedorismo & $\begin{array}{l}\text { i) } 60 \% \text { da população é assalariada; } \\
\text { ii) Número elevado de empresários; } \\
\text { iii) } 30 \% \text { das pessoas que compõem a força de trabalho e ainda não estão envolvidas } \\
\text { com empreendedorismo pretendem abrir um negócio nos próximos três anos; } \\
\text { iv) Maioria dos empreendedores são homens; } \\
\text { v) Os empreendedores latino-americanos investem mais em negócios informais que } \\
\text { países desenvolvidos, porém, os valores que investem são menores; } \\
\text { vi) Abrem um negócio por avistar uma oportunidade; } \\
\text { vii) Empreendedorismo é visto como uma boa opção de carreira, que proporciona } \\
\text { elevado status e tem atenção da mídia; e } \\
\text { viii) As pessoas percebem oportunidades e tem as capacidades necessárias para } \\
\text { iniciar novos empreendimentos, porém, o medo de fracassar é considerável e pode } \\
\text { impedir o início desses negócios. }\end{array}$ \\
\hline
\end{tabular}


CONTEXTO

Inovação

i) Introduzem novos produtos com menos frequência que as empresas de economias parecidas;

ii) Investimento em Pesquisa e Desenvolvimento (P\&D) é baixo;

iii) A quantidade de registros de patentes é menor que em outros países comparados;

iv) Poucos engenheiros;

v) Países latino-americanos investem mais em ciências sociais e ciências agrícolas;

vi) $\mathrm{O}$ financiamento de $\mathrm{P} \& \mathrm{D}$ continua altamente concentrado em instituições públicas (agências governamentais e universidades); e

vii) A maioria dos países latino-americanos exporta menos tecnologias que outros países.

Fonte: Elaboração a partir dos dados da pesquisa.

\section{CONSIDERAÇÕES FINAIS}

$\mathrm{Na}$ atualidade, com a globalização e a inter-relação que ela proporciona, os países estão constantemente se comunicando e mantendo relações comerciais. $O$ mundo transformou-se em uma economia do conhecimento onde o grau e a velocidade com que uma sociedade absorve novas tecnologias, obtém e compartilha informação em escala mundial, bem como cria, dissemina novos conhecimentos e determina a sua capacidade para operar e competir (BID, 2011).

Para manter-se nesse ambiente e não sofrer danos, os países precisam adequar-se às exigências do ambiente competitivo, melhorando a forma como empreendem e utilizando a inovação como um recurso-chave para o desenvolvimento de suas economias. A América Latina, região que engloba vários países, incluindo o Brasil, ao longo dos anos, teve crescimentos e desacelerações econômicas, estas últimas prejudiciais e que podem afetar ganhos que a população latino-americana já adquiriu na área social. Nesse contexto, o estudo objetivou compreender o perfil do empreendedorismo e inovação na América Latina.

Como proposta, sugere-se que o governo crie programas ou melhore os já existentes para aumentar a consciência dos empresários a respeito do papel da inovação tecnológica no aumento da eficiência e da lucratividade das empresas. Nesse sentido, faz-se relevante, também, educar as pessoas para que entendam a importância de outras áreas de estudo, bem como o registro de patentes para assegurar suas invenções e inovações. Do mesmo modo, é importante que fiquem atentos aos empreendedores por necessidade, pois índices elevados sugerem que há algo de errado com a economia, visto que eles só estão criando negócios porque não têm outra opção. 
A pesquisa limitou-se a alguns países selecionados pela autora - como América Latina -, portanto percebe-se a viabilidade de um estudo em outras regiões ou países. Como proposta para estudos futuros a partir do tema deste estudo, recomenda-se uma pesquisa voltada a outras regiões ou um aprofundamento maior sobre a América Latina, visto que muitos outros fatores podem influenciar o empreendedorismo além da inovação.

Assim, conclui-se que o tema é bastante relevante para profissionais de administração, sociologia e economia, assim como para acadêmicos que buscam mais informações a respeito. Nesse sentido, também pode ser importante para os governos, visto que são eles que podem buscar soluções para os itens em que a América Latina não se sobressai.

\section{REFERÊNCIAS}

ANDRADE, M. M. de. Como preparar trabalhos para cursos de pós-graduação: noções práticas. 5. ed. São Paulo: Atlas, 2002.

ANDREASSI, T. et al. Empreendedorismo no Brasil. Disponível em: <http://www. gemconsortium.org/docs/download/2806>. Acesso em: 4 maio 2015.

AYERBE, L. F. Estados Unidos e América Latina: a construção de hegemonia. São Paulo: UNESP, 2002.

BANCO INTERAMERICANO DE DESENVOLVIMENTO - BID. La Necesidad de Innovar: El camino hacia el progreso de América Latina y el Caribe. Disponível em: <http:// craig.com.ar/biblioteca/La\%20necesidad\%20de\%20Innovar.\%20Camino\%20 hacia\%20el\%20Progreso\%20-\%20BID.pdf>. Acesso em: 28 abr. 2015.

BÁRCENA, A. et al. Latin America and the Caribbean in the World Economy: Regional integration and value chains in a challenging external environment. Chile: ECLAC, 2014. 141 p. Disponível em: <http://www.cepal.org/publicaciones/xml/2/53952/ PANINSAL2014_en.pdf>. Acesso em: 25 nov. 2014.

BESSANT, J.; TIDD, J. Inovação e empreendedorismo. Porto Alegre: Artmed, 2009.

BETHELL, L. O Brasil e a ideia de "América Latina" em perspectiva histórica. Estudos Históricos, Rio de Janeiro, v. 22, n. 44, p. 289-321, jul./dez. 2009.

BOHOSLAVSKY, E. ¿Qué es América Latina? El nombre, la cosa y las complicaciones para hablar de ellos. Los Polvorines, Buenos Aires: Conicet, 2009. 
COMISSÃO ECONÔMICA PARA A AMÉRICA LATINA E O CARIBE - CEPAL. Anuario Estadístico de América Latina y el Caribe. Chile: CEPAL, 2014. Disponível em: <http://repositorio.cepal.org/bitstream/handle/11362/37647/S1420569_ mu.pdf?sequence=1>. Acesso em: 25 nov. 2014.

COMISSÃO ECONÔMICA PARA A AMÉRICA LATINA E O CARIBE - CEPAL. Estadísticas e Indicadores Económicos. Disponível em: <http://interwp.cepal.org/sisgen/ ConsultalntegradaFlashProc_HTML.asp>. Acesso em: 30 abr. 2015.

D'ARAUJO, M. C. Prospectos da democracia na América Latina em 2006. Rio de Janeiro: CPDOC/FGV, 2006, p. 1-13.

FARRET, R. L.; PINTO, S. R. América Latina: da construção do nome à consolidação da ideia. TOPOI, [s.I.], v. 23, n. 12, p. 30-42, jul./dez. 2011. Semestral. Disponível em: <http://www.revistatopoi.org/numeros_anteriores/topoi23/topoi23_a02_ america_latina.pdf>. Acesso em: 28 abr. 2015.

FERES JUNIOR, J. Spanish America como o outro da América. Lua Nova: Revista de Cultura e Política, São Paulo, n. 62, p. 69-91, 2004.

FERREIRA, F. H. G. et al. Economic Mobility and the Rise of the LAC Middle Class. Washington: World Bank, 2013.

GIL, A. C. Como elaborar projetos de pesquisa. 4. ed. São Paulo: Atlas, 2007.

GINDLING, T. H.; NEWHOUSE, D. L. Self-Employment in the Developing World. World Bank: Washington, 2012.

GLOBAL ENTREPRENEURSHIP MONITOR - GEM. Women's Report, 2010. Disponível em: <http://www.ibqp.org.br/upload/tiny_mce/_GEM_2010_Women_Report. pdf>. Acesso em: 2 maio 2015.

GLOBAL ENTREPRENEURSHIP MONITOR - GEM. Visualizations, 2015. Disponível em: <http://www.gemconsortium.org/visualizations>. Acesso em: 25 abr. 2015.

GLOBAL ENTREPRENEURSHIP MONITOR - GEM. Empreendedorismo no Brasil, 2004. Disponível em: <http://www.dce.sebrae.com.br/bte/bte. nsf/1EC939C7F8E5D50503256FE200487D4A/\$File/NT000A6806.pdf>. Acesso em: 4 maio 2015.

GWYNNE, R. N.; CRISTOBAL, K. Latin America Transformed: Globalization and Modernity. 2. ed. Nova lorque: Routledge, 2014. 
INSTITUTO DE ESTATÍSTICA DA UNESCO - UIS. América Latina y el Caribe: Informe regional países. [S.I.], 2001. Disponível em:<http://data.uis.unesco.org/>. Acesso em: 28 abr. 2015.

LEDERMAN, D. etal. Latin American Entrepreneurs: Many Firms but Little Innovation. Washington: World Bank, 2014. Disponível em: <http://www.worldbank.org/ content/dam/Worldbank/document/LAC/LatinAmericanEntrepreneurs.pdf>. Acesso em: 15 ago. 2014.

MEZA, M. L. F. G. de et al. O perfil do empreendedorismo nos países latinoamericanos na perspectiva da capacidade de inovação. Revista da Micro e Pequena Empresa, Campo Limpo Paulista, v. 2, n. 2, p. 58-75, set. 2008. Disponível em: <http://www.faccamp.br/ojs/index.php/RMPE/article/view/45/36>. Acesso em: 20 abr. 2015.

MORSE, R. M. O Espelho de Próspero. São Paulo: Cia das Letras, 1988.

ORGANIZAÇÃO DAS NAÇÕES UNIDAS PARA A ALIMENTAÇÃO E A AGRICULTURA - FAO. América Latina y el Caribe, 1997. Disponível em: <http://www.fao.org/ docrep/v8300s/v8300s0o.htm>. Acesso em: 29 abr. 2015.

ORGANIZAÇÃO DAS NAÇÕES UNIDAS PARA A EDUCAÇÃO, A CIÊNCIA E A CULTURA - UNESCO. Informe Regional sobre la Educación para Todos en América Latina y el Caribe: Reunión Mundial de Educación para Todos. Paris: UNESCO, 2012. Disponível em: <http://www.unesco.org/new/fileadmin/MULTIMEDIA/HQ/ED/ED_new/pdf/ LAC_SP.pdf>. Acesso em: 8 out. 2014.

ORGANIZAÇÃO INTERNACIONAL DO TRABALHO - OIT. Panorama Laboral 2013: América Latina y el Caribe. Lima: OIT/Oficina Regional para América Latina y el Caribe, 2013. 136 p. Disponível em: <http://www.ilo.org/wcmsp5/groups/public/--americas/---ro-lima/documents/publication/wcms_232760.pdf>. Acesso em: 8 out. 2014.

QUIJANO, A. Dom Quixote e os moinhos de vento na América Latina. Estudos Avançados, [S.I.], v. 19, n. 55, p. 9-31, dez. 2005. Disponível em: <http://www. revistas.usp.br/eav/article/view/10091>. Acesso em: 7 out. 2014.

RUAS, R. Gestão por competência: uma contribuição à estratégia das organizações. In: RUAS, R. et al. Os novos horizontes da gestão: aprendizagem organizacional e competências. Porto Alegre: Bookman, 2005. 
SCHUMPETER, J. A. A teoria do desenvolvimento econômico. São Paulo: Nova Cultural, 1985.

SOUZA, A. de. América Latina, conceito e identidade: algumas reflexões da história. PRACS: Revista Eletrônica de Humanidades do Curso de Ciências Sociais da UNIFAP, Macapá, n. 4, p. 29-39, 2012.

STALLINGS, B.; PERES, W. Crescimento, emprego e equidade: o impacto das reformas econômicas na América Latina e Caribe. Rio de Janeiro: Campus, 2002.

UNITED NATIONS DEVELOPMENT PROGRAMME - UNDP. About Latin America and the Caribbean. [On-line] Sem data de publicação. Disponível em: <http:// www.latinamerica.undp.org/content/rblac/en/home/regioninfo/\#Introduction >. Acesso em: 29 abr. 2015. 